Volume 11

Issue 1 Information and Communications

Technologies in Mass Atrocities Research and

Article 17

Response

$5-2017$

\title{
Book Review: The History of a Forgotten German Camp: Nazi Ideology and Genocide in Szmalcówka
}

Darren J. O'Brien

University of Queensland, University of Sydney

Follow this and additional works at: https://digitalcommons.usf.edu/gsp

\section{Recommended Citation}

O'Brien, Darren J. (2017) "Book Review: The History of a Forgotten German Camp: Nazi Ideology and Genocide in Szmalcówka," Genocide Studies and Prevention: An International Journal: Vol. 11: Iss. 1:

122-125.

DOI:

http://doi.org/10.5038/1911-9933.11.1.1438

Available at: https://digitalcommons.usf.edu/gsp/vol11/iss1/17

This Book Review is brought to you for free and open access by the Open Access Journals at Digital Commons @ University of South Florida. It has been accepted for inclusion in Genocide Studies and Prevention: An International Journal by an authorized editor of Digital Commons @ University of South Florida. For more information, please contact digitalcommons@usf.edu. 


\title{
Book Review: The History of a Forgotten German Camp: Nazi Ideology and Genocide in Szmalcówka
}

\author{
Darren J. O'Brien \\ University of Queensland \\ Brisbane, Australia \\ University of Sydney \\ Sydney, Australia
}

\author{
The History of a Forgotten German Camp: Nazi Ideology and Genocide in Szmalcówka \\ Tomasz Ceran \\ London, I.B. Tauris, 2015 \\ 256 Pages; Price: \$95.00 Hardcover
}

Reviewed by Darren O'Brien

University of Queensland, School of Historical and Philosophical Inquiry; University of Sydney, School of Nursing; Australian Institute for Holocaust and Genocide Studies, Australia

Tomasz Ceran's work provides a microhistory of the establishment, thirty-three month existence, and functioning of one small Nazi camp called Szmalcówka, located in Toruń, northern Poland during World War II. In similarity with other camps of the vast Nazi camp network, the purpose and role of Szmalcówka changed over the course of its existence contingent on exigencies for the Germans at a given time. Established in 1940, the camp was initially described in German documents as a Sammellager (transit camp), later as an Umwandererlager (resettlement camp) and eventually, before it closed in mid-1943, as an Arbeitserziehungslager (educational work camp). Over the course of the German occupation, the initial organized transfer of people through the camp gave way to a fixed residency for forced laborers. This was followed by the permanent captivity of civilians and, undeniably, a premeditated expectation of the death of Poles, in particular, children who remained in the camp from secondary exposure to disease and starvation. Though never specified or functioning as a German Vernichtungslager (extermination camp) per se, Szmalcówka did serve as a camp in which mass murder through intentional malnutrition, overcrowding, inadequate response to sickness, injury, and life threatening disease prevailed. In addition, physical abuse and sporadic murder, not systematic execution, were commonplace. As Ceran relates, Attorney Małgorzata Wójcik summarized at the end of the last investigation into the camp conducted in 2010:

the behaviour of the authorities of the camp-deliberately and consciously making life as difficult as possible for the people in the camp, in numerous ways, leading to the biological destruction of this life-bears all the attributes of a crime-the crime of genocide. ${ }^{1}$

Szmalcówka was established in December 1940, on the site of the former First National Lard Processing and Packing factory at 124/126 Grudziądzka Street, Toruń. The factory buildings had been constructed a decade earlier by Szarf Selma, a Polish Jew who fled the Germans in 1939.2 The factory site was attractive to the Germans because it was situated in close proximity to the General Government, especially Warsaw, and it was also located close to Łódź in the Reichsgau Wartheland - the newly established German location for the settlement of ethnic Germans. What is more, Szmalcówka was located in an industrial area with a railway siding. During the war, the railway infrastructure was used to facilitate the deportation of Poles from the surrounding region, now redefined in accordance with Nazi racial regulations and policy, to, from, and via the newly established camp Szmalcówka. In other words, the camp was established after the initial wave of mass killings of the Polish intelligentsia following the German invasion of Poland and,

\footnotetext{
${ }^{1}$ Tomasz Ceran, The History of a Forgotten German Camp: Nazi Ideology and Genocide in Szmalcówka (London: I.B. Tauris, 2015), 50.

${ }^{2}$ Ibid., 50.
} 
operated to facilitate aggregation, racial screening, segregation, and the dispersal of Poles along racial and economic lines. As Ulrich Greifelt, the Reich Commissioner for the Consolidation of German Nationhood, explained in May 1940:

While 'the removal of persons of alien race from the annexed eastern territories is one of the most important aims to be achieved in the German East,' it is equally imperative 'to regain for the German nation the German blood in these districts, even in cases where the person concerned is Polonised in language and religion.' It is 'an absolute national-political necessity to screen the annexed Eastern territories and, later, the Government General also for such persons of Teutonic blood, to make this lost German blood available to our people again. ${ }^{\prime 3}$

Polish civilians from surrounding areas, mainly farmers who were expelled from their properties and had their land expropriated, were brought to Szmalcówka. Those deemed to exhibit German blood, Volksdeutsche-Germans in terms of people, folk or race, or ethnic Germans according to often arbitrary ${ }^{4}$ Nazi evaluation, would be forced to "re-settle," predominantly in the Reichsgau Wartheland, if not sent to the Reich proper to work. Ethnic Poles on the other hand, viewed as subhuman Slavs lacking Germanic blood were to be deported to the General Government or held to work. A premature death would come to them, and was intended for them, sooner or later. This process of Entpolisierung (Depolonisation) or clearing Poland of racially alien Poles and Jews by all means included slave labor and mass murder. Ceran quotes Hans Frank, Nazi Governor General of the Occupied Polish Territories in 1942,

The evacuation of Poles, and their destruction or treatment exclusively as manpower is the task of our Polish policy.... What should be said here is this: all those Poles we're using for work, we keep; while the rest, we eradicate. The great difficulty, however, lies in the fact that the extermination of millions of human beings is a project which we are not yet able to deal with. ${ }^{5}$

As an example of arrival and distribution at Szmalcówka, the first two transports of Polish families evicted from their properties arrived between 20 and 30 November 1940. This included forty-one families from Tczewo, fifty-nine families from Nowe Miastro Lubawskie, twenty-five families from Bydgoszcz, 106 families from Torun, forty-two families from Rypin, twenty-three families from Świecie, thirty-eight families of Chełmno, twenty-eight families from Grudziądz, seven families from Tuchola, four families from Lipno and three families from Starogard Gdański. ${ }^{6}$ Of these 1,358 individuals sent from Szmalcówka to the General Government, 185 were hired by the employment office in Toruń, 119, deemed of German blood, were sent to Łódź in the Reichsgau Wartheland, as suitable for Germanisation, thirty-two were released (including twelve Soviet citizens and two women with children), while twelve Poles remained in the camp. ${ }^{7}$ Over the course of the following two years an average of 1,500 people arrived at the camp per month. Conditions were always substandard. At commencement, bales of hay were scattered on the cement around the inside of the four halls of the factory to serve as bedding pallets and three army field kitchens were installed within the former boiler room. Buckets were used as toilets. These quickly overflowed. It took eight months of operation before a washroom was installed. No heating was installed to offset frozen Polish winters. Leaking roofs went unrepaired. After the initial period of concerted forays into separating out "valuable German blood" in the region had subsided, and as the course of the war changed, more people remained incarcerated in Szmalcówka. Eventually transports arrived

\footnotetext{
${ }^{3}$ As quoted in the Nuremberg Military Tribunals. "The RuSHA Case," Trials of War Criminals, 15 Vols. (Washington, D.C.: Government Printing Office, 1950), 4:762f.

${ }^{4}$ To be born in Prussia, for example, was often enough to constitute German ethnicity.

${ }^{5}$ Ceran, The History of a Forgotten German Camp, 59.

${ }^{6}$ Ibid., 60 .

${ }^{7}$ Ibid., 61.
} 
but did not leave. By May 1943, one and a half months before the camp was closed, 2,319 remained there, most of them children, too young to work. The above mentioned factors, experienced over the course of the life of the camp, resulted in regular overcrowding, infestation with fleas and lice, typhus epidemics and death secondary to malnutrition, food poisoning, starvation, illness, physical injury or murder.

Ceran's book, not overly lengthy at 256 pages, is divided into five chapters with two appendices. The first chapter, entitled "An Ideological Crusade," encompasses Ceran's theory of German motivation for their policy and actions in the East, including Szmalcówka. Although I did not necessarily disagree with Ceran's views in this chapter, I found the chapter wanting. At twentytwo pages it was too short to adequately unpack the ideas he relates including his own exposition of the Nazi worldview with Antisemitism; Imperialism and Social Darwinism; Anti-Slavism and Anti-Polishness; and Nationalism and Chauvanism emanating around a central cog of Racism. Concepts of modernity, Gemeinschaft and Gesellschaft, the loss of WWI and the persona of Hitler, were touched upon very briefly. Scientific racism and eugenic theory informed Hitler's (and the Nazi) worldview well before the $1930 \mathrm{~s}^{8}$ and the organized evaluation, segregation, transport, and murder of the disabled - "life unworthy of life" established a logistical roadmap for later wartime actions. These details, along with the role of beneficiaries, bystanders, the willing participants, accomplices, conspirators, aiders and abettors as enactors of the Nazi worldview as concepts are missing from Ceran's work. But perhaps they should be, as that was not the level at which Ceran was focusing in this chapter, nor what a book about Szmalcówka camp was about. That is my point, instead of an overly brief chapter on ideology; I would have much preferred here a chapter on the history of Torun and how and why this location was important to the Germans. How did this town change over the course of the war and the role of Szmalcówka camp in that change, perhaps in a similar vein to the work of Deborah Dwork and Robert J. Van Pelt, Auschwitz, 1270 to the present. ${ }^{9}$

Chapters two to five of Ceran's book describe the underpinning concepts (Depolonisation) and process of Nazi Polish policy in the region, as summarized above, and provide a detailed description of a number of people incarcerated in the camp as well as conditions within the camp at various periods of its existence. Ceran's work contains a multitude of Tables, Figures, maps and line drawings, some completed by the author. Given that no physical remains of the site exist today and that no photographic images of the camp have been located in the author's quite comprehensive examination of local archival sources, these drawings proved useful to this reader. Appendix one contains ten well-selected documents - two German and seven Polish, in English translation - that I found most valuable in rounding out my understanding of Ceran's prose in various sections of his work.

A central concern for Ceran, and one I agree with is an essential obligation of the historian, is accuracy, empathy, and remembrance in historiography. Toward this end, in painstaking fashion, Ceran has gathered, compared, and contrasted all previously known names, ages, and causes of death of Polish victims who died in the Szmalcówka camp, including one child not listed in any formal documentation, but known to the mother who lost her child there. More than a narrative history, Ceran's book therefore, additionally, becomes a Memorbuch or memorial book, based upon an updated examination and correction of the historical record and the latest extant documentation. Ceran's tabulation of these details (Table 5.1) constitutes twenty-seven pages or 12 percent of his entire work.

Ceran's book is largely derived from his investigation and analysis of Polish language documents especially, that can be found in the various regional and state archives located in Bydgoszcz, Gdańsk, Torun, and Warsaw. His most important sources are the collections of the Polish regional commission for the investigation of Nazi crimes in Bydgoszcz, at its branch in Torun, held between 1968 and 1976. As well as the materials collected anew by the branch commission for investigation of crimes against the Polish nation in Gdansk, leading the proceedings in Bydgoszcz held between 2005 and 2010. These sources are supplemented with survivor memoirs and witness

\footnotetext{
${ }^{8}$ Edwin Black, War Against the Weak: Eugenics and America's Campaign to Create a Master Race (New York: Four Walls Eight Windows, 2003), 259.

${ }^{9}$ Deborah Dwork and Robert Jan Van Pelt, Auschwitz, 1270 to the Present (New York: W. W. Norton \& Company, 1996).
} 
testimony as well as regional histories. I was somewhat puzzled by the omission of the use of Bundesarchiv resources, for example SS Officer Records or the NSDAP central card index, that may have facilitated Ceran's profiles of camp Commandants and guard perpetrators based at the camp over the course of its existence.

Tomasz Ceran's book makes a valuable contribution to the history of the treatment of the Polish people under Nazi race and resettlement policy during World War II. It is solidly based on Polish archival documents yet sensitively conveys the sense of chaos - "hunger, displacement, expulsion from home, beatings, executions and forced labour for the Germans" - experienced by the Poles of the region and in the camp. ${ }^{10}$ The work would suit senior students and academics of World War II history and genocide studies.

${ }^{10}$ Ceran, The History of a Forgotten German Camp, 7. 